\title{
MEASUREMENT AND PREDICTION OF TREE GROWTH REDUCTION FROM TREE PLANTING SPACE DESIGN IN ESTABLISHED PARKING LOTS
} by Jason Grabosky ${ }^{1}$ and Edward Gilman ${ }^{2}$

\begin{abstract}
Five species of trees were measured in 12- to 27-yearold parking lots in north-central Florida, U.S. Tree species evaluated were Chinese elm (Ulmus parvifolia Jacq.), live oak (Quercus virginiana Mill.), sycamore (Platanus occidentalis L.), shumard oak (Q. shumardii Britton), and laurel oak (Q. laurifolia Michx.). Tree growth in the parking lot planting zones was reduced as the surface area of nonpaved surface was reduced for all trees except live oak. Regression models yielded significant relationships with prediction value between parking lot detail space openings and tree size, measured by diameter at breast height or by canopy radius. Normalization of the data within the site allowed for multiple site analysis. A method for generating similar data is introduced for development of regionally speciesspecific growth reduction multipliers. Those multipliers can be used to better meet long-term canopy expectations or to advocate for larger planting zones.
\end{abstract}

Key Words. Chinese elm; live oak; sycamore; shumard oak; laurel oak; canopy size; trunk dbh; tree height.

Concerns for environmentally sustainable urban development and planning have grown with increases in urbanization, exemplified by catchphrases such as "smart growth" and increased legislation with regard to environmental impacts. Outgrowths of these concerns are the development of community forest management plans and the adoption of municipal shade tree ordinances. Within many ordinances, and in recommendation templates for ordinance development, there is language for the assignment of minimum canopy cover in the design of parking lots and industrial development areas (Lee County 1990; ISA 2001; City of Sacramento 2003).

Design of parking areas usually provides for some level of tree canopy establishment, in balance with space concerns and capacity parking issues (ISA 2001; Garber 2000a, 2000b, 2000c). Tree ordinance language often provides formulae for calculating the required number of individual trees. Methods include using a canopy cover percentage, meeting a canopy target per unit of paved area, using a set number of trees per unit paved of area, or mandating vegetation space per number of parking spaces. Often when a percentage of cover is mandated, there is a time frame imposed for such a designated level of coverage target to be fulfilled, such as $50 \%$ shade of the lot within 15 years (ISA 2001; Barr Engineering 2001; City of Sacramento 2003). A limitation of the growth prediction method is the lack of measured tree growth impacts from the parking lot environment, and the unfortunate lack of prophetic prowess of professionals for estimating attrition, car hits, maintenance damage severity, pavement resurfacing needs (accounting for the 15- to 25-year criterion), and design changes over time.

While field wisdom and experience is useful, quite often professionals charged with the design of planting spaces have little or no training or experience beyond any casual personal observation. Alternatively, the designer may consult an industry contact who also relies on general observation rather than measurement. As a result, ordinance requirements may be met by creating tree planting spaces and tree species selection with tree growth expectations based on references for tree growth in parklike or natural settings (Dirr 1990; Gerhold et al. 1993; Bassuk 1998; Gilman 1997; Porter 2000). Such references do not report reduced growth or basic tree-pavement design limitations; thus, designs meet the design letter of the law in planning for canopy but fail to meet the intent of the law due to lack of growth (McPherson 2001). While there is anecdotal evidence that trees in parking lots are smaller than those growing in less stressful environments, little data are available to document the effect. The goal of this study was to determine the relationship between canopy area to diameter at breast height (dbh) and attempt a fitting coefficient for growth expectation based on site restrictions as represented by open soil surface in the planting zone in parking lot design detail. The information was used to evaluate the expectation of growth in varied design details for planning parking lot tree planting spaces to better meet the provisions of municipal tree ordinances.

\section{MATERIALS AND METHODS}

In 2002, parking areas located throughout north-central Florida, U.S., were selected for data collection to test the hypothesis of decreased canopy expectations for parking lot trees. Twelve- to thirty-year-old parking lots at malls, shopping centers, colleges, and universities were identified. Upon securing permission from owners, each site was visited prior to data collection to verify adequate numbers of trees, the availability of suitable species, and the presence of a variety of tree-pavement design strategies. All sites required a test species in the parking lot as well as the same species planted on the periphery of the lot in nonrestricted soil areas as part of the site construction project. Sites of 
Table 1. Site identification project age and species present on site for canopy analysis.

\begin{tabular}{|c|c|c|c|c|c|c|}
\hline Site & $\begin{array}{l}\text { Age in } \\
\text { years }\end{array}$ & Elms & $\begin{array}{l}\text { Live } \\
\text { oaks }\end{array}$ & Sycamores & $\begin{array}{l}\text { Shumard } \\
\text { oaks }\end{array}$ & $\begin{array}{l}\text { Laurel } \\
\text { oaks }\end{array}$ \\
\hline UF O'Connell Center & $20+$ & & 39 & & & \\
\hline UF Track & $20+$ & & & & 19 & \\
\hline Oaks Mall & 24 & 52 & 24 & 49 & & \\
\hline Newberry Square & 16 & & 27 & & & 41 \\
\hline Santa Fe C.C. 'A' & 11 & & & 10 & & \\
\hline Santa Fe C.C. 'B,' 'C,' 'D' & $20+$ & & 34 & & & \\
\hline Santa Fe C.C. 'E' & 15 & 7 & & & & \\
\hline Paddock Mall & 20 & 117 & & & & \\
\hline Shands Hospital & $20+$ & & & & 24 & \\
\hline Orange Park Mall & 27 & & 49 & & & \\
\hline Avenues Mall & 12 & 111 & 68 & & & \\
\hline The Park & $15+$ & & & 19 & & \\
\hline Total trees & & 287 & 241 & 78 & 43 & 41 \\
\hline
\end{tabular}

protocol for trunk diameter followed recommendations in the Guide for Plant Appraisal (CTLA 2000). Soil openings without pavement were measured and assigned into a size class rounded up to the nearest $9.29 \mathrm{~m}^{2}\left(100 \mathrm{ft}^{2}\right)$. For regression analysis of measured tree parameters against available nonpaved space, several assumptions were placed on the delineation of the nonpaved root zone area. Where trees shared a planting zone, the total zone was divided by the number of trees in the zone. Where pavement openings intersected at points less than $15 \mathrm{~cm}$ (6 in.) wide, the planting zones were considered separately, unless visual evidence was present that the roots were in both profiles. Where trees fit into an "unlimited" soil zone, the soil volume for further analysis was arbitrarily set to be 2 times the area within the

data collection are shown with replicate counts in Table 1. Tree species evaluated were Chinese elm (Ulmus parvifolia Jacq.), live oak (Quercus virginiana Mill.), sycamore (Platanus occidentalis L.), shumard oak (Q. shumardii Britton), and laurel oak (Q. laurifolia Michx.). The species were chosen because of their prevailing use and availability throughout the region.

Initial treatment codes were assigned to each tree based on the size and shape of their respective island, strip, and open planting area and their proximity to curbs and pavement (Table 2). The design details encountered were parking lot edge (large rooting zone, portion of canopy over pavement), closed knuckle divider (zone surrounded by pavement used to direct traffic flow), open knuckle divider (surrounded by pavement and directing traffic flow, but connected to open soil at one end), and vegetation strips [long, interconnected root zone, placed in three classes: $<1 \mathrm{~m}$ ( $3.3 \mathrm{ft}$ ) wide, 1 to $3 \mathrm{~m}$ (3.3 to $10 \mathrm{ft}$ ) wide, and $>3 \mathrm{~m}$ $(10 \mathrm{ft})$ wide]. Sites used as controls featured open soil, no pavement below canopy, and a large rooting zone. For better interpretation, the zones were measured for area of nonpaved soil surface.

All trees on the site were measured and used except those known to be replacement trees for earlier losses. Tree height to the nearest $0.31 \mathrm{~m}(1 \mathrm{ft})$ was determined using a Suunto clinometer from a distance of $30.48 \mathrm{~m}(100 \mathrm{ft})$. Average canopy radius was calculated from north, east, south, and west canopy measurements to the nearest $15 \mathrm{~cm}$ (6 in.) from tape measure center from trunk to branch tip. The area below the drip line was calculated as a circle from the mean canopy radius per tree. Trunk diameter (dbh) was measured to the nearest $1 \mathrm{~mm}(0.04 \mathrm{in}$.) at $1.37 \mathrm{~m}(4.5 \mathrm{ft})$ above soil. Trunk diameter on multiple trunks, the elms, were calculated by the square root of the summation of the individual trunk diameters squared. The measurement drip line of the tree where no curbs were within $5 \mathrm{~m}$ (16.5 $\mathrm{ft}$ ) of the trunk, and 1.5 times the area within the drip line in cases where pavement was within $5 \mathrm{~m}$ of the trunk. To prevent undue influence in the regression relationship, the mean of the control group calculated areas was used to generate a group endpoint for the regression analysis, rather than regressing on the relationship generated from the calculated soil areas based on the size of the control canopies.

At older commercial sites, landscape maintenance companies had changed hands over the years, as had ownership and management. Documentation indicating planting dates and installed tree size was difficult to acquire, when existent, and site maintenance profiles (pruning, fertilization, and irrigation) were inconsistent. Additionally, site conditions pertaining to construction,

Table 2. Description of treatment groupings in parking lot design analysis. Number of curbs was assigned for analysis of canopy size by design type.

\begin{tabular}{ll}
\hline Treatment group & Number of curbs \\
\hline $\begin{array}{l}\text { Parking edge distant } \\
\text { Parking edge close }\end{array}$ & 0 \\
Vegetation strip & 1 \\
$>3 \mathrm{~m}$ & 2 \\
$1-3 \mathrm{~m}$ & 2 \\
$<1 \mathrm{~m}$ & 2 \\
Dual tree narrow oval & 2 \\
$\quad(>3: 1$ dimension ratio $)$ & \\
& \\
Columnar knuckle, L and T & 3 if connected to larger soil zone \\
Columnar knuckle, L and T & 4 if not connected to larger soil zone \\
Triangulated knuckle & 3 if connected to larger soil zone \\
Triangulated knuckle & 4 if not connected to larger soil zone \\
Classic tree pit opening & 4 \\
$\quad(<3: 1$ dimension ratio) & \\
\hline
\end{tabular}


soils, and weather were unmeasured variables due to geographic variability, site logistics, and labor and testing costs. Construction norms, however, were regionally consistent, and the assumption was made that construction practice was at least consistent within a parking lot. Therefore, to gain an understanding of growth and performance in each of the given treatments, trees were analyzed on a site-to-site basis.

Data from each species were used to generate dbh-tocanopy radius, and dbh-to-height relationships with simple linear regression, with a notation of published size expectations (Dirr 1990; Gilman 1997). Measured tree parameters were normalized within their respective sites. Each data point was divided by the site control group mean for any given parameter. The normalization allowed for multiple site analysis and comparison and provided a simple method to suggest design multipliers if meaningful relationships were detected, because the data would represent a percentage reduction from expected growth. Analysis of variance within site by species was tested for treatment differences based on curb presence and opening size class. Data were then analyzed by the curb/class mean of a given parameter in a simple linear regression over the multiple sites, reported with confidence intervals and prediction bands for clarity on data variability within each class. Analysis was conducted in MINITAB release 12 (Minitab 1998).

\section{RESULTS}

\section{Platanus occidentalis}

Canopy radius was closely related to dbh $\left(r^{2}=0.901\right)$, but the height-dbh relationship, while significant, as inferred from the $\alpha=0.95$ confidence intervals (Neter et al. 1996), was not as closely related $\left(r^{2}=0.68\right)$ (Figure $\left.1 \mathrm{a}, \mathrm{b}^{*}\right)$. From the $\alpha=0.95$ prediction bands (Neter et al.1996), height could be expected to vary as much as $10 \mathrm{~m}$ (33 ft) compared to the $2 \mathrm{~m}(6.6 \mathrm{ft})$ variability in the radius prediction intervals. Observed upper size ranges of 18 to $20 \mathrm{~m}$ (59.4 to $66 \mathrm{ft})$ height and $8 \mathrm{~m}(26.4 \mathrm{ft})$ radius were close to the expectation of 28 to $30 \mathrm{~m}$ ( 92.4 to $99 \mathrm{ft}$ ) height and diameter for the species as reported in tree selection texts (Dirr 1990; Gilman, 1997). The normalized canopy radius (relative to respective site control tree groups) was closely related to the number of curbs in the parking lot design details on the sites (Figure 1c). This was due to the very thin dimensioning in many cases, with enclosed spaces (four curbs) falling into spaces less than $10 \mathrm{~m}^{2}\left(11.9 \mathrm{yd}^{2}\right)$ in open area (Figure 1d). Whether measured by detail type or space accommodation, trees in the more limiting situations were observed to have a canopy radius $50 \%$ to $60 \%$ of those in the open control spaces. Because the observations are canopy radii, the actual reduction of canopy area (calculated like a circle, based on observed radii) ranged from $64 \%$ to $75 \%$ (see appendix). The relationship between

*Figures appear on pp. 160-164. open space and tree canopy radius was significant and can be used to predict reductions in growth with openings less than $10 \mathrm{~m}^{2}$ with reasonable accuracy (Figure $1 \mathrm{~d}$ ).

\section{UImus parvifolia}

Canopy radius and height were significantly related to dbh, but less closely than in the sycamore $\left(r^{2}=0.73\right.$ and 0.61 , respectively) (Figure 2a,b). Maximal size observations fell within the expectation of 12 to $15 \mathrm{~m}$ (39.6 to $49.5 \mathrm{ft}$ ) height and width for the species as reported in tree selection texts (Dirr 1990; Gerhold et al. 1993; Gilman 1997). Due to the common presence of multiple stems that influenced canopy radius depending on their angle of departure from the main axis of growth, dbh was chosen as a preferred measure to observe any reductions in growth associated with nonpaved space. Due to variable dimensions of the linear strips and generally wider spaces associated with wider-lower branching habits, the relationship between normalized dbh and curb number was weak, $\left(r^{2}=0.387\right)$ and of little predictive value. The relationship between $\mathrm{dbh}$ and nonpaved area was significant, and spaces less than $80 \mathrm{~m}^{2}\left(95.8 \mathrm{yd}^{2}\right)$ were observed to have a dbh of $50 \%$ to $65 \%$ of their associated nonrestricted controls (Figure 2c). The spread confidence intervals reflect the lack of certainty of the relationship based on the available data, particularly in the larger spaces.

Similarly, the prediction bands demonstrate that predicting individual performance is limited because trees in the most limited spaces could easily grow to $80 \%$ of expectations of the control situation and trees in open spaces could be $70 \%$ of expectations. Of course, as a group, there are significant reductions in growth with decreases in open space $\left(r^{2}=\right.$ 0.631)(Figure 2c).

\section{Quercus shumardii}

Canopy radius and height were significantly related to dbh $\left(r^{2}=0.652\right.$ and 0.397 , respectively) (Figure $\left.3 a, b\right)$. Maximal size observations of 18 to $23 \mathrm{~m}(59.4$ to $75.9 \mathrm{ft})$ height and 5 to 7 ( 16.5 to $23.1 \mathrm{ft}$ ) $\mathrm{m}$ radius fell within the growth expectation of $18 \mathrm{~m}(59.4 \mathrm{ft})$ height and 12 to $18 \mathrm{~m}(39.6$ to $59.4 \mathrm{ft}$ ) diameter for the species as reported in tree selection texts (Dirr 1990; Gerhold et al. 1993; Gilman 1997). Many of the larger dbh trees in limited spaces had large, dead main leaders or removed limbs on sites where irrigation was not present or operational, influencing the height and, to a lesser extent, the radius data sets. While the relationship between space and tree size was significant $\left(r^{2}=0.881\right)$, more data in intermediate size ranges would have been helpful to verify the nature of the potentially curvilinear relationship and increase the prediction interval power in the regression analysis. Trees with less than $75 \mathrm{~m}^{2}$ $\left(89.7 \mathrm{yd}^{2}\right)$ space were on average $65 \%$ to $80 \%$ the radius of their related controls (Figure $3 \mathrm{c}$ ). 


\section{Quercus laurifolia}

Canopy radius and height were significantly related to dbh $\left(r^{2}=0.818\right.$ and 0.611 , respectively) (Figure $\left.4 a, b\right)$, although the relationship is compromised due to limited replication (Table 3). Maximal size observations of 12 to $15 \mathrm{~m}$ (39.6 to $49.5 \mathrm{ft}$ ) height and 6 to $7 \mathrm{~m}$ (19.8 to $23.1 \mathrm{ft}$ ) radius fell within the expectation of growth of 12 to $18 \mathrm{~m}$ (29.6 to $59.4 \mathrm{ft}$ ) height and 9 to $12 \mathrm{~m}$ (29.7 to $39.6 \mathrm{ft}$ ) width for the species as reported by Dirr (1990) but less than 18 to $21 \mathrm{~m}$ (59.4 to $69.3 \mathrm{ft}$ ) height as reported by Gilman (1997). While a relationship between space and tree size was present $\left(r^{2}=0.249\right)$, the relationship had no predictive value for reduced growth that would be of any consequence wherein the most limited site averaged over $90 \%$ of the controls (Figure 4c).

\section{Quercus virginiana}

Canopy radius and height were significantly related to dbh $\left(r^{2}=0.719\right.$ and 0.448 , respectively) (Figure 5a, b). Maximal size observations of 15 to $20 \mathrm{~m}$ (49.5 to $66 \mathrm{ft}$ ) height and 10 $\mathrm{m}(33 \mathrm{ft})$ radius fell on the low end of the expected 18 to 24 m (59.4 to $79.2 \mathrm{ft}$ ) height and 18 to $36 \mathrm{~m}$ (59.4 to 118.8 ) diameter (Dirr 1990; Gilman 1997), which was anticipated given the age of the tree compared to the mature stature and habit of the species. There was no relationship found between open space and tree size, with the best-fit line having a slope of zero growth increase with change of open space (Table 4), and an $r^{2}<0.002$. Adding site and/or age into the model did not yield any substantially improved relationship.

\section{DISCUSSION}

It is not surprising to see a species difference in growth reduction as a response to increasingly limited sites, particularly in a 10- to 25-year time frame. The lack of response in the oaks make predictions for performance based on planting space provisions problematic, yet they do provide evidence for lowering expectations for growth. The data, in all cases except live oak, make clear that if ordinance goals are based on canopy growth over time, the design either has to increase planting spaces for normal growth expectation or accept diminished growth and increase the number of trees in the planting design.

Regression analysis of tree size parameters yielded significant relationships between dbh and both height and canopy radius. Additionally, the largest trees in each species grouping were reasonably close to published size expectations. The larger trees were consistently in the control group and in the parking lot edge group.

No data were collected to explain the cause of the impact. It is presumed that the elevated soil temperature profiles, water limitations (at either extreme), and compaction requisite for sound pavement construction contribute to the lack of easily colonized, viable soil to ensure growth expectations. Root limiting and lethal temperatures have been measured below pavement surfaces (Graves 1998). Compaction norms for construction are often beyond levels observed to limit plant growth (Holtz and Kovacks 1981; Daddow and Warrington 1983). Water can be limited due to catchment areas and surrounding sealed surfaces and its inability to reach the planting zone due to curbs. Water in the soil can have problems infiltrating the surrounding compacted profile; thus, water can be an issue of excess or drought within the same site.

Additionally, no information was collected on the "fitness" of the species selection or the quality of the soil in the nonlimiting planting situations or in planting practices. Salt tolerance and soil $\mathrm{pH}$ issues may limit the species deemed appropriate for limiting situations, as can disease
Table 3. Comparison of regression line slopes and confidence intervals for five tree species in established north-central Florida parking lots.

\begin{tabular}{|c|c|c|c|}
\hline \multirow[b]{2}{*}{$\begin{array}{l}\text { Dependent variable } \\
\text { Independent variable } \\
\text { Species }\end{array}$} & \multicolumn{3}{|c|}{$\begin{array}{c}\text { Slope of regression line } \pm 95 \% \text { confidence interval } \\
\text { Relationship in regression analysis }\end{array}$} \\
\hline & $\begin{array}{l}\text { Canopy radius } \\
\text { dbh }\end{array}$ & $\begin{array}{l}\text { Tree height } \\
\text { dbh }\end{array}$ & $\begin{array}{l}\text { Canopy radius } \\
\text { Pavement opening }\end{array}$ \\
\hline Platanus occidentalis & $0.130 \pm 0.010$ & $0.306 \pm 0.048$ & $27.2 \pm 9.9 *$ \\
\hline Ulmus parvifolia & $0.135 \pm 0.010$ & $0.183 \pm 0.017$ & $0.166 \pm 0.056$ \\
\hline Quercus shumardii & $0.099 \pm 0.023$ & $0.173 \pm 0.067$ & $0.085 \pm 0.036$ \\
\hline Quercus laurifolia & $0.111 \pm 0.017$ & $0.180 \pm 0.047$ & $0.166 \pm 0.260 * *$ \\
\hline Quercus virginiana & $0.096 \pm 0.008$ & $0.107 \pm 0.015$ & $0.003 \pm 0.043 * * *$ \\
\hline
\end{tabular}

and pest presence. Quite often the best tree selection can be compromised by poor planting practices on the part of the installation subcontractor.

This study used the surviving trees in standard operating design-installation practices for the area, using standard tree selections for the area during that time. Differences in species response have to be considered before generalizing the data. Known species differences to root zone temperature (Graves 1998) and observed invasive potential [tree of heaven (Ailanthus altissima ((Mill.) Swingle) versus sugar 
maple (Acer saccharum (Marsh.)] also impact the relationships between design growth expectation and surviving reality. The growth of live oak compared to shumard oak or sycamore in this study illustrates the point.

The data are limited to Florida, and more data are needed to gain a comprehensive idea on how to scale down growth expectations for new designs. The levels of acceptance for growth or legislated levels of canopy are not truly enforceable over the 15-year timeline, and little additional money is provided for creative design to meet normal growth expectations. This study was a needed first step to suggest a predictive method for design planning to encourage better site designs for tree establishment. The method can be adapted to use existing tree inventories with species, $\mathrm{dbh}$, and GIS data to determine the standardized opening size classes for analysis. Site identification and the development of the canopy radius to dbh relationship are needed steps for direct translation that can be quickly developed within small regions on the most popular species used. As data are developed, the information should be collected into a general site for analysis and comparison to develop a more generalized concept for growth reduction expectation based on data, if such generalizations can be found, and then communicated to people expected to make informed design decisions. Such data can also then consider many variables, such as soil conditions after construction, heat load, and irrigation influences to refine and ameliorate such impacts.

\section{LITERATURE CITED}

Bassuk, N. 1998. Recommended Urban Trees: Site

Assessment and Tree Selection for Stress Tolerance.

Cornell University Urban Horticulture Institute, Ithaca, NY. 69 pp.

Barr Engineering Company. 2001. Minnesota Urban Small Sites BMP Manual: Stormwater Best Management Practices for Cold Climates: Parking Lot Design Requirements. Metropolitan Council on Environmental Services, St. Paul, MN.

City of Sacramento. California. 2003. Parking Lot Tree Shading Design and Maintenance Guidelines: Section II: Shading Requirements and Calculations. City of Sacramento, Sacramento, CA.

Council of Tree and Landscape Appraisers (CTLA). 2000. Guide for Plant Appraisal (9th ed.). International Society of Arboriculture, Champaign, IL. 143 pp.

Daddow, R.L., and G. E. Warrington. 1983. GrowthLimiting Bulk Densities As Influenced by Soil Texture. US Forest Service WSDG Report WSDG-TN-00005.
Dirr, M. 1990. Manual of Woody Landscape Plants (4th ed.). Stipes Publishing. Champaign, IL. 1,007 pp.

Garber, M.P. 2000a. Natural Resource Conservation: Components of a Tree and Landscape Ordinance, Part I. University of Georgia College of Agriculture and Life Sciences Departmental Publication H-00-057. 4 pp.

- 2000b. Natural Resource Conservation: Components of a Tree and Landscape Ordinance, Part II. University of Georgia College of Agriculture and Life Sciences Departmental Publication H-00-058. 4 pp.

- 2000c. Natural Resource Conservation: Components of a Tree and Landscape Ordinance, Part IIII. University of Georgia College of Agriculture and Life Sciences Departmental Publication H-00-059. 4 pp.

Gerhold, H., N. Lacasse, and W. Wandell (Eds.). 1993. Street Tree Fact Sheets. Municipal Tree Restoration Program, University Park, PA. 385 pp.

Gilman, E.F. 1997. Trees for Urban and Suburban Landscapes. Delmar Publishing, Albany, NY. 662 pp.

Graves, W.R. 1998. Consequences of high soil temperatures, pp 27-35. In Neely, D., and G. Watson (Eds.). The Landscape Below Ground II. International Society of Arboriculture, Champaign, IL.

Holtz, R.D., and W.D. Kovacks. 1981. Introduction to Geotechnical Engineering. Prentice Hall, Englewood Cliffs, NJ. 733 pp.

International Society of Arboriculture (ISA). 2001. Guidelines for Developing and Evaluating Tree Ordinances: Part 2, Provision 25. www.isa-arbor.com/ publications/ordinance.asp (accessed 3/26/04).

Lee County, Florida. 1990. Ordinance No. 90-22. Section C.5.e.(2)(b), Internal Landscaping of Parking Areas. Board of Commissioners, Lee County, FL.

McPherson, E.G. 2001. Sacramento's parking lot shading ordinance: Environmental and economic costs of compliance. Landscape Urban Plann. 57:105-123.

Minitab. 1998. MINITAB Release 12 Users Guide 2. Minitab, Inc., State College, PA.

Neter, J., M. Kuter, C.J. Nachtsheim, and W. Wasserman. 1996. Applied Linear Statistical Models (4th ed.). Irwin, Inc. Chicago, IL.

Porter, W. (Ed.). 2000. Trees for New Jersey Streets, (4th rev.). New Jersey Shade Tree Federation, New Brunswick, NJ. 29 pp.

Acknowledgments. Thanks to the TREE Fund Hyland R. Johns program for funding this project. 


\section{APPENDIX}

\begin{tabular}{llll}
\hline $\begin{array}{l}\text { Percentage of } \\
\text { canopy radius }\end{array}$ & $\begin{array}{l}\text { Example } \\
\text { radius }\end{array}$ & $\begin{array}{l}\text { Area of } \\
\text { example }\end{array}$ & $\begin{array}{l}\text { Percentage } \\
\text { reduction } \\
\text { canopy area }\end{array}$ \\
\hline 100 & 50 & 7854 & 0 \\
90 & 45 & 6362 & 19 \\
80 & 40 & 5027 & 36 \\
70 & 35 & 3849 & 51 \\
60 & 30 & 2827 & 64 \\
50 & 25 & 1964 & 75 \\
40 & 20 & 1257 & 84 \\
30 & 15 & 707 & 91 \\
20 & 10 & 314 & 96 \\
10 & 5 & 79 & 99 \\
\hline
\end{tabular}

${ }^{1 *}$ Assistant Professor

Department of Ecology, Evolution and Natural Resources

Rutgers University

144 Environmental and Natural Resources Building

14 College Farm Road

New Brunswick, NJ 08901, U.S.

${ }^{2}$ Professor

Environmental Horticulture Department

University of Florida

Gainesville, FL 32611, U.S.

*Corresponding author.

Résumé. Cinq espèces d'arbres âgés de 12 et 27 ans situés dans des stationnement du Centre-Nord de la Floride ont été mesurés. Les espèces évaluées étaient de l'orme chinois (Ulmus parvifolia Jacq.), du chêne de Virginie (Quercus virginiana Mill.), du platane occidental (Platanus occidentalis L.), du chêne de Shumard (Q. shumardii Britton) et du chêne à feuilles de laurier (Q. laurifolia Michx.). La croissance des arbres dans les espaces de plantation des stationnements diminuait avec la réduction de la surface non pavée autour des arbres, et ce dans tous les cas à l'exception du chêne de Virginie. Les modèles de régression ont produits des résultats significatifs en regard de la prédiction entre la superficie non pavée et les valeurs de dimension des arbres, de diamètre au DHP ou de rayon de cime. La normalisation des données à l'intérieur d'un site permet de réaliser de multiples analyses de site. Une méthodologie pour générer des données similaires est proposée pour le développement de facteurs multiplicatifs locaux de réduction de croissance par espèce. Ces facteurs multiplicatifs peuvent être utilisés pour mieux évaluer et rencontrer les attentes en regard du développement de la cime à long terme ou encore pour plaider l'emploi de plus grandes fosses de plantation.

Zusammenfassung. In Nordflorida wurden auf Parkplätzen 5 Baumarten zwischen 12 und 27 Jahren vermessen. Die bewerteten Baumarten waren: Chinesische Ulme (Ulmus parvifolia Jacq.), Lebenseiche (Quercus virginiana Mill.), Platane (Platanus occidentalis L.), Shumard Eiche (Quercus shumardii Britton), und Lorbeereiche (Quercus laurifolia Michx.). Mit der Reduktion der ungepflasterten Fläche wurde auch das Baumwachstum mit Ausnahme der Lebenseiche reduziert. Die Regressionsmodelle ergaben signifikante Beziehungen mit der Möglichkeit großer Vorhersage zwischen den Raumverhältnissen auf den Parkplätzen und der Baumgröße, die mit Brusthöhendurchmesser oder Kronendurchmesser gemessen wurden. Die Anpassung der Daten innerhalb des Standorts berücksichtigte vielseitige Standortanalysen. Eine Methode, um ähnliche Daten zu erzeugen, wurde hier für die Entwicklung von artspezifischen wachstumshemmenden Multiplikatoren bei regionalen Arten eingeführt. Jene Multiplikatoren können benutzt werden, um auf lange Sicht die Wachstumserwartungen der Baumkronen besser einzuschätzen und entsprechend größere Pflanzgruben zu befürworten.

Resumen. Se midieron especies de árboles entre 12 y 27 años de edad en lotes de aparcamiento de la región nortcentral de Florida. Las especies evaluadas fueron olmo chino (Ulmus parvifolia Jacq.), encino virginiano (Quercus virginiana Mill.), sicomoro (Platanus occidentalis L.), encino shumard (Quercus shumardii Britton) y encino laurel (Quercus laurifolia Michx.). El crecimiento de los árboles se redujo con relación a la superficie pavimentada, a excepción de encino virginiano. Los modelos de regresión mostraron una relación significativa en los valores predichos entre las áreas abiertas libres de pavimento y el tamaño de los árboles, medido por el diámetro a la altura del pecho o por el radio de la copa. La normalización de los datos dentro del sitio permitió realizar un análisis múltiple. Se introduce un método para generar datos similares mediante el desarrollo de factores específicos regionalmente por especies. Estos factores pueden ser usados para encontrar a largo plazo mejores expectativas para plantación en grandes zonas. 

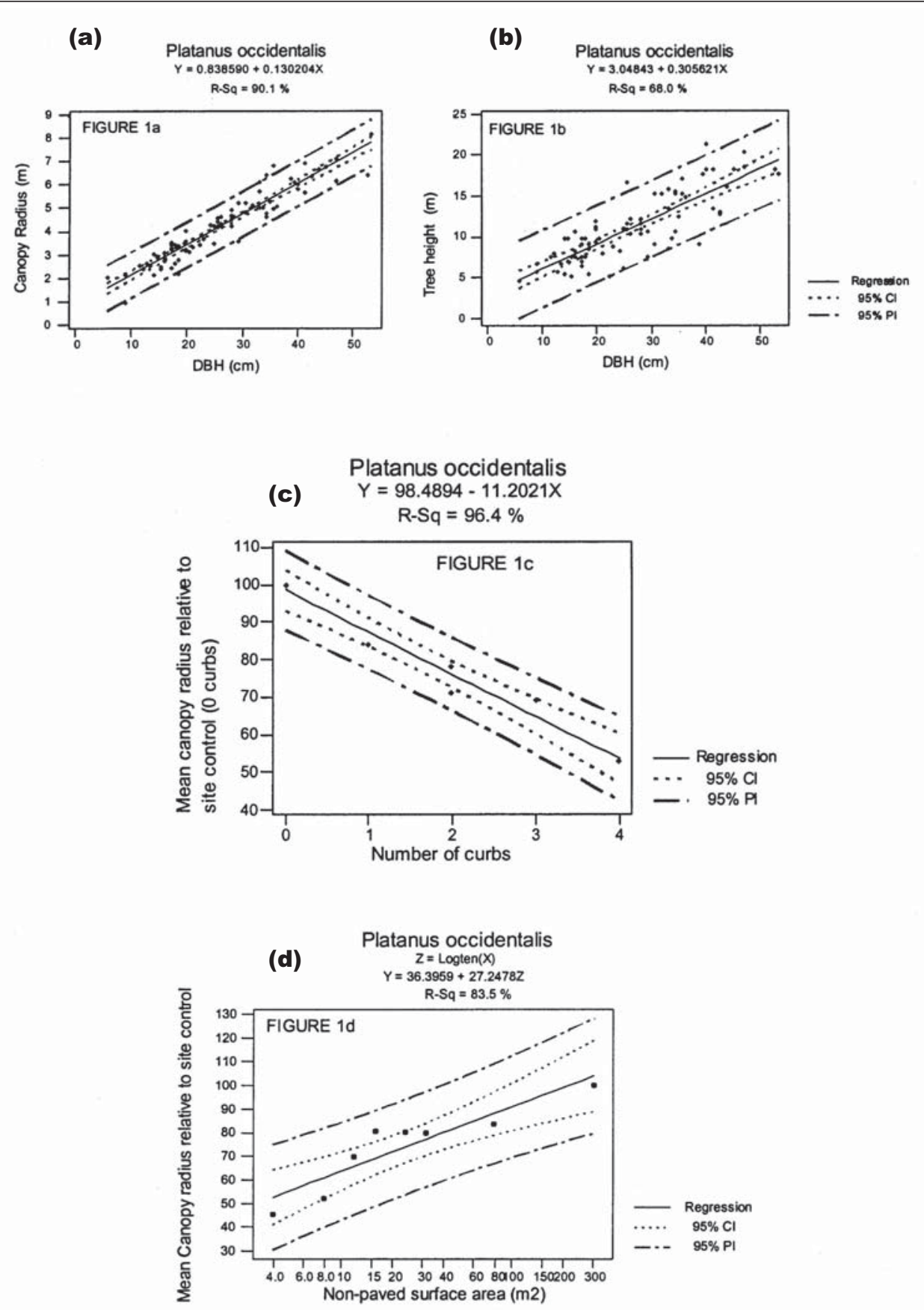

Figure 1. Canopy size relationships of Platanus occidentalis in north-central Florida parking lots.

$\mathrm{CI}=$ confidence interval for the regression line from the existing data set at $\mathbf{a}=\mathbf{0 . 0 5}$.

PI = prediction interval for new observations at $\alpha=\mathbf{0 . 0 5}$ for trees observed beyond the data set subject to the same criteria of treatment, species, age, region, and analysis.

la. Simple linear regression relationship of canopy radius to $\mathrm{dbh}$.

1b. Simple linear regression relationship of tree height to $\mathrm{dbh}$.

1c. Simple linear regression relationship of canopy radius to number of curbs in design detail. Canopy radius data points represent mean radii, normalized to mean canopy radius for on-site control groups to fit multiple sites into analysis.

1d. Simple linear regression relationship of canopy radius (log 10$)$ to open soil space in the design detail. Canopy radius data points represent mean radii within pavement opening size groups, normalized to mean canopy radius for on-site control groups to fit multiple sites into analysis. 


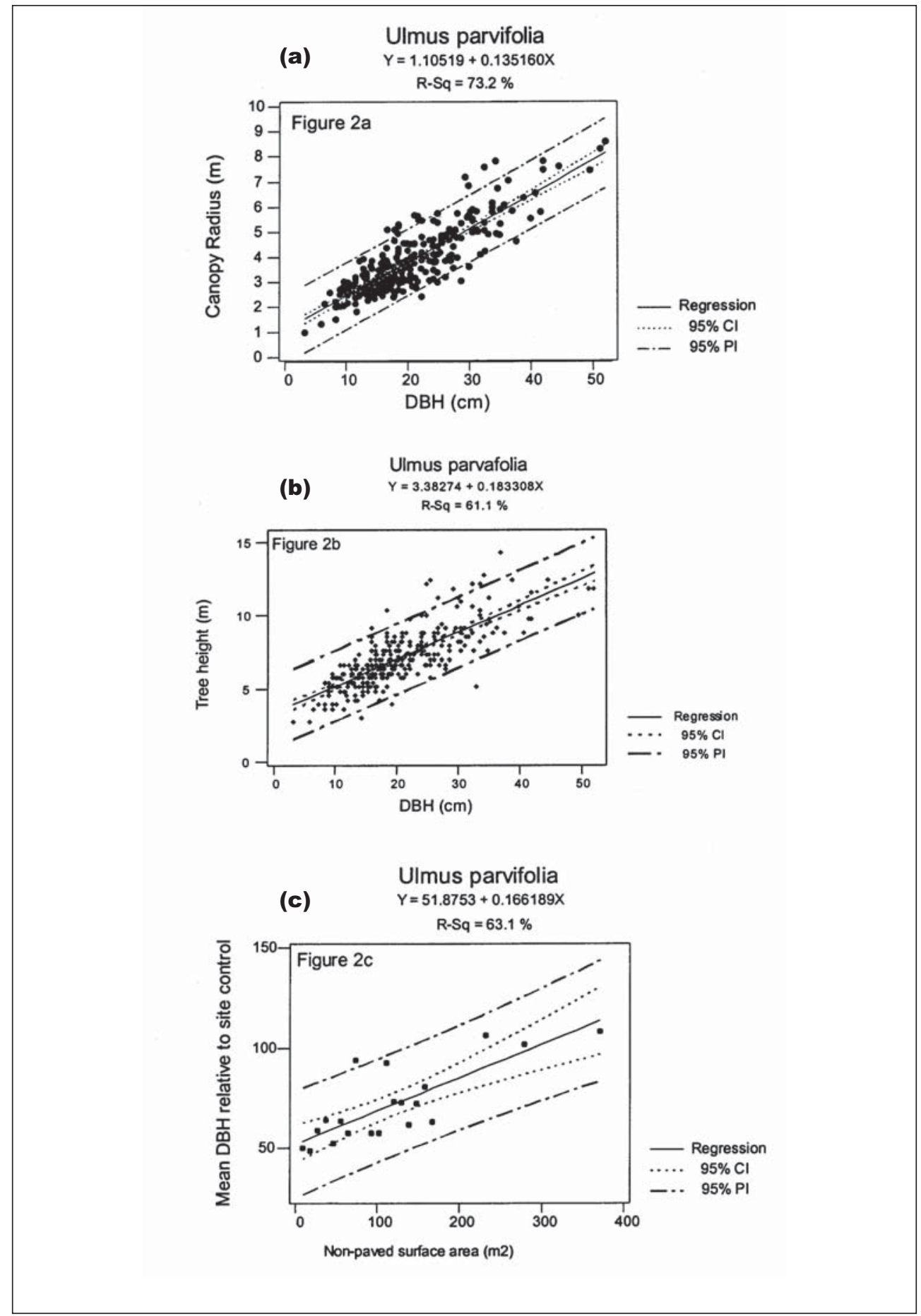

Figure 2. Canopy size relationships of Ulmus parvifolia in north-central Florida parking lots.

$\mathrm{CI}=$ confidence interval for the regression line from the existing data set at $\mathrm{a}=\mathbf{0} \mathbf{0 . 0 5}$.

PI = prediction interval for new observations at $\alpha=\mathbf{0 . 0 5}$ for trees observed beyond the data set subject to the same criteria of treatment, species, age, region, and analysis.

2a. Simple linear regression relationship of canopy radius to $\mathrm{dbh}$.

2b. Simple linear regression relationship of tree height to $\mathrm{dbh}$.

2c. Simple linear regression relationship of canopy radius to open soil space in the design detail. Canopy radius data points represent mean radii within pavement opening size groups, normalized to mean canopy radius for onsite control groups to fit multiple sites into analysis. 


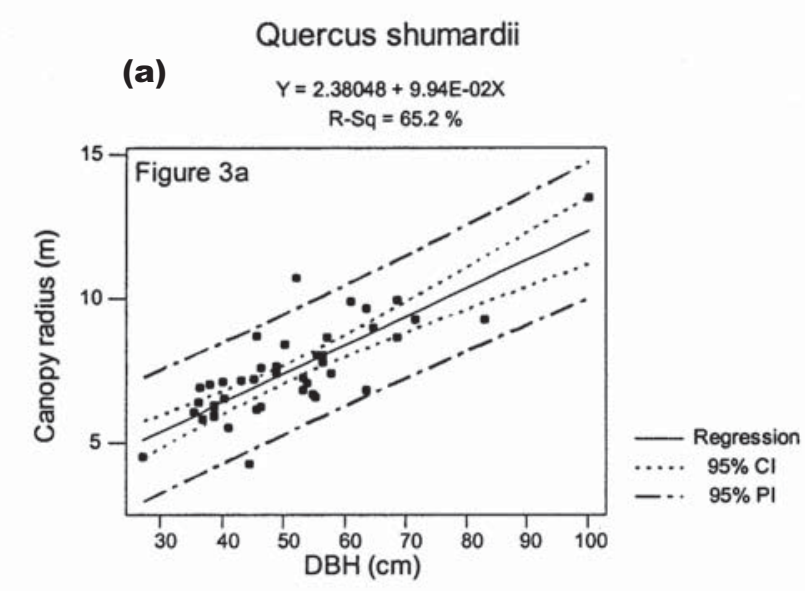

(b) Quercus shumardii

$Y=6.09907+0.172597 X$ $\mathrm{RSq}=39.7 \%$

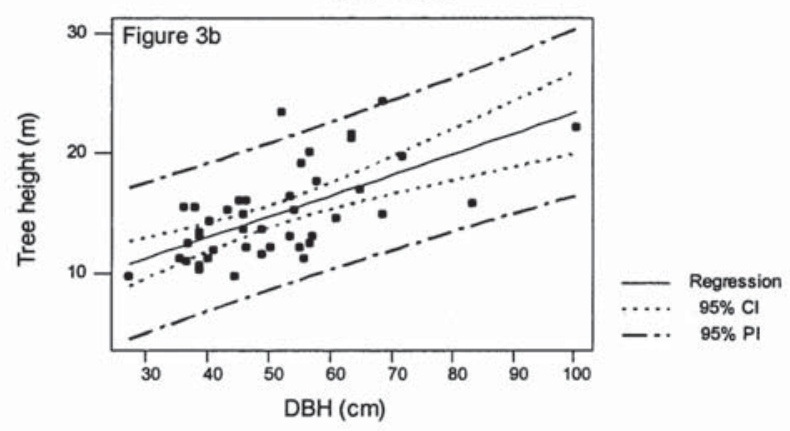

(c)

Quercus shumardii

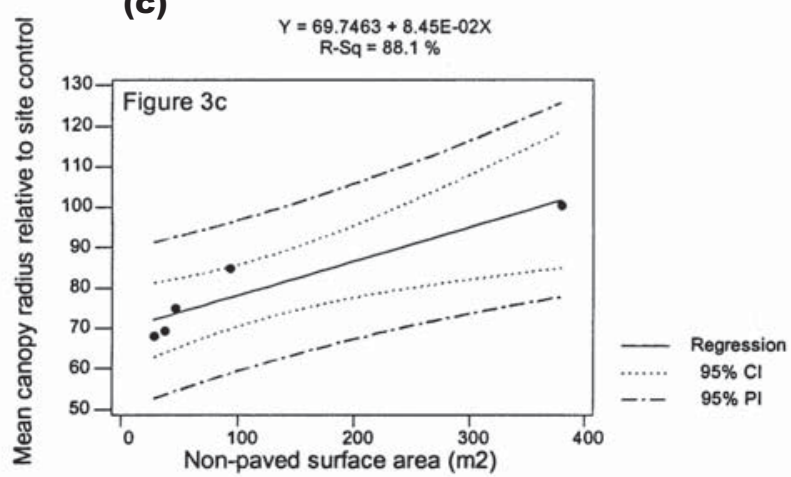

Figure 3. Canopy size relationships of Quercus shumardii in north-central Florida parking lots.

$\mathrm{CI}=$ confidence interval for the regression line from the existing data set at $\mathbf{a}=0.05$.

PI = prediction interval for new observations at $\alpha=0.05$ for trees observed beyond the data set subject to the same criteria of treatment, species, age, region, and analysis.

3a. Simple linear regression relationship of canopy radius to $\mathrm{dbh}$.

3b. Simple linear regression relationship of tree height to $\mathrm{dbh}$.

3c. Simple linear regression relationship of canopy radius to open soil space in the design detail. Canopy radius data points represent mean radii within pavement opening size groups, normalized to mean canopy radius for onsite control groups to fit multiple sites into analysis. 


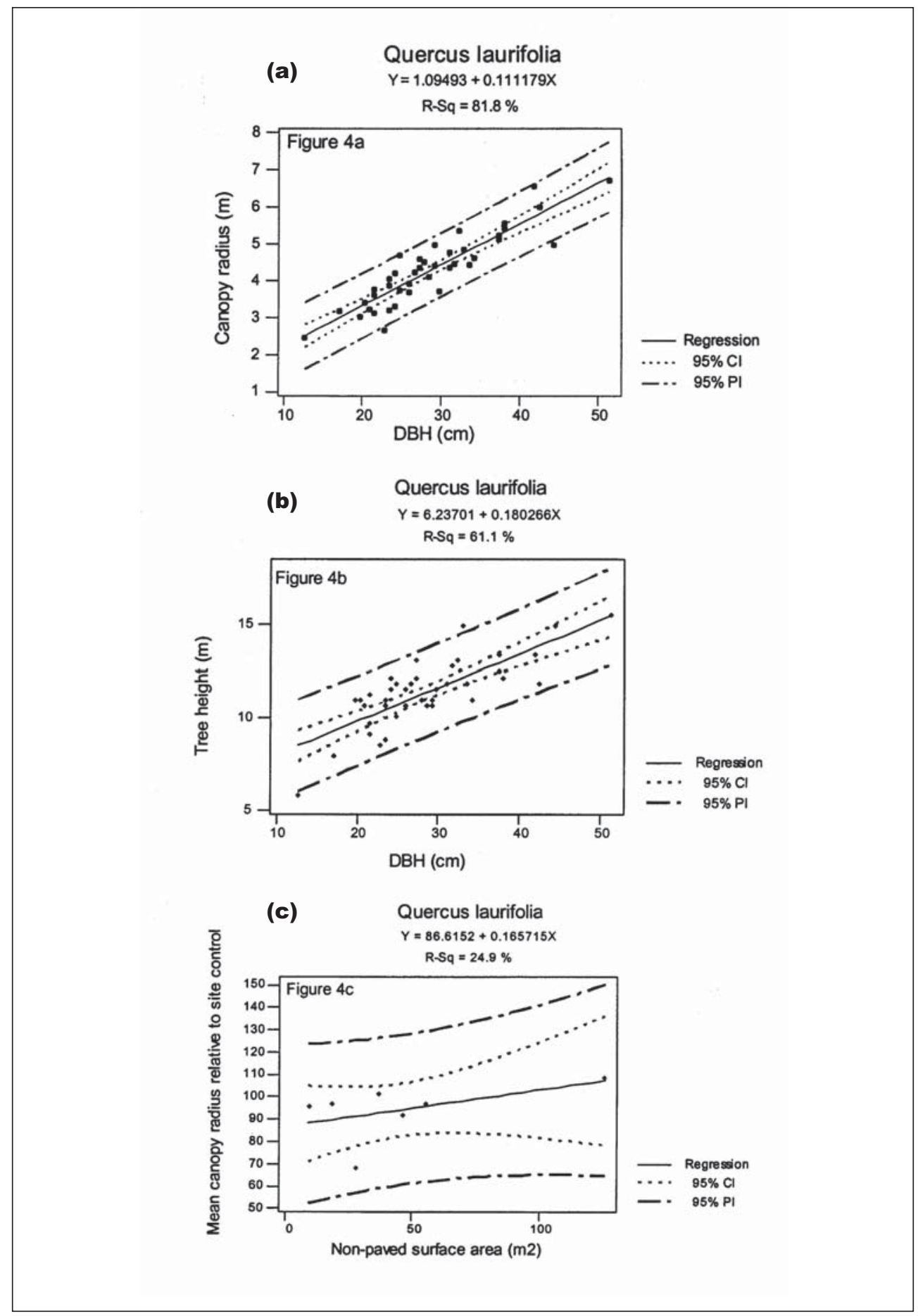

Figure 4. Canopy size relationships of Quercus laurifolia in north-central Florida parking lots.

$\mathrm{CI}=$ confidence interval for the regression line from the existing data set at $\mathbf{a}=0.05$.

PI = prediction interval for new observations at $\alpha=0.05$ for trees observed beyond the data set subject to the same criteria of treatment, species, age, region, and analysis.

4a. Simple linear regression relationship of canopy radius to $\mathrm{dbh}$.

4b. Simple linear regression relationship of tree height to $\mathrm{dbh}$.

4c. Simple linear regression relationship of canopy radius to open soil space in the design detail. Canopy radius data points represent mean radii within pavement opening size groups, normalized to mean canopy radius for onsite control groups to fit multiple sites into analysis. 

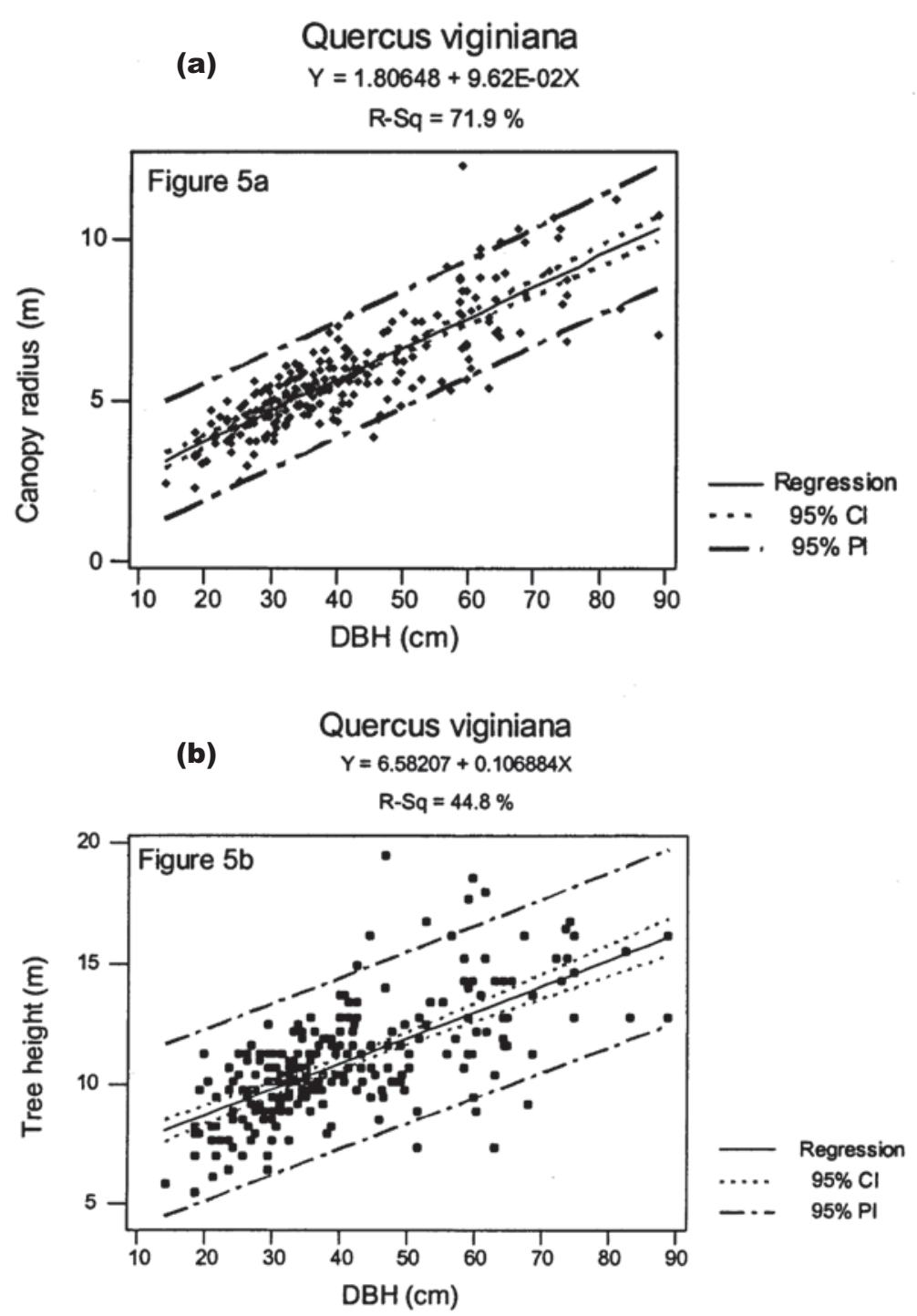

Figure 5. Canopy size relationships of Quercus virginiana in north-central Florida parking lots.

$\mathrm{CI}=$ confidence interval for the regression line from the existing data set at $\mathbf{a}=\mathbf{0 . 0 5}$.

PI = prediction interval for new observations at $\alpha=0.05$ for trees observed beyond the data set subject to the same criteria of treatment, species, age, region, and analysis.

5a. Simple linear regression relationship of canopy radius to $\mathrm{dbh}$.

$5 \mathrm{~b}$. Simple linear regression relationship of tree height to $\mathrm{dbh}$. 